\title{
A Step Towards an Inclusive Digital Transformation of the Public Administration in a Developing Country: Evidence From Morocco
}

\author{
Jihane Aayale, $\mathrm{PhD}$ \\ Dept. of Economics, Groupe ISCAE, Casablanca \\ E-mail: jaayale@iscaextra.net \\ Meriem Seffar, $\mathrm{PhD}$ \\ Dept. of Finance, Groupe ISCAE, Casablanca \\ E-mail: mseffar@iscaextra.net
}

Received: May 9, 2021 Accepted: June 9, $2021 \quad$ Online published: June 28, 2021

doi:10.5296/jpag.v11i2.18598ＵRL: https://doi.org/10.5296/jpag.v11i2.18598

\begin{abstract}
The digital revolution has fundamentally transformed everyone's daily lives, and that includes the public administration, that finds itself in an interesting predicament, either to take advantage of these changes and therefore be committed to modernise its processes and services, or see itself become out of touch with the public, its main customer. With that, many studies enumerate the prowess of industrialised developed countries when it comes to the digitalisation of public services; but developing countries have entered the digital race as well, and a significant increase in digital public services' use demonstrates the efforts made by public authorities in developing nations to meet citizens' expectations, and to capitalise on the digital experience for the digital, social and financial inclusion. Taking Morocco as an example, the structural, organisational, managerial, digital and ethical reform of the public administration is at the heart of Morocco's societal project. With the aim of analysing the digitised public services scenery in Morocco and the impact of their implementation, a qualitative study was conducted in two of the most important public administrations of the kingdom, the General Tax Management Agency (DGI) and the National Agency for Land Conservation, Cadastre and Cartography (ANCFCC). The results show that transition to the digital age allows for improvements and that its impacts can already be observed, and that important implications of social and financial inclusion are to keep in mind, especially during
\end{abstract}


a global pandemic.

Keywords: public administration, digital transformation, e-government, inclusion, developing country

\section{Introduction}

Nowadays, citizens can actively participate in society through a number of online tools, enabling the digital transformation of citizenship. By digital citizenship, we mean the citizens' and the companies' right of access to all data, documents and services that interest them in a digital manner. To achieve digital citizenship, it's necessary to achieve the digitalisation of public administrations, which is often referred to in the literature as e-government, a digital administration.

The notion of e-government has evolved, due to rapid changes in the field of information technology. The European Commission (2003), defined e-government as "the use of information and communication technologies in public administrations combined with organisational change, as well as new skills to improve public services and democratic processes thus strengthening support for public policies."

The process of digitalisation of public administration is part of a strategy that aims to improve access to goods and services for both citizens and enterprises, but also aims to harness the potential of information technologies to promote innovation, sustainability, economic growth and development.

This means reconsidering and redefining processes and services from a user-centric digital perspective, offering through the promotion of digital citizenship rights to civil and economic society, open access to data and services.

When indicating the perimeter in which the administration must plan its digitalisation, the main aspects for the implementation of the digital transformation process are first and foremost, but not limited to, the management of costs in IT infrastructure. Indeed, an information system for the public administration needs to ensure the interaction and exchange of information and to distinguish between data of national interest, exchanged between administrations, and data that's accessible to the public, ensuring not only availability, but integrity and confidentiality of information; the governance of digital transformation goes through many challenges, such as the reorganisation of processes and the development of human capital.

For more than 20 years, questions have been asked about the absorption capacity of innovative processes in ecosystems as rigid as public administrations, whose history shows changes and innovations, mainly in developed countries. Nowadays, the concept of innovation is strongly linked to technology and most governments and countries, at different level of economic development, are familiarised with the notions of digital transformation and e-government.

Towards this end, the aim of this paper is to show how Morocco, as a developing country, has taken a very important step towards e-government, and to our best knowledge, digital 
transformation strategies in the Moroccan public administration have never been addressed from this angle in the existing literature, leaving a gap it'd be interesting to try and fill.

This article endeavours to explore the aforementioned notions, starting by laying the groundwork with a theoretical framework on the history of public management and the impact information and communication technologies have had on its evolution, moving on to two case studies of a developing world nation's public administrations, and finally a section of discussion of the results of the qualitative studies and their digital, social and financial inclusion implications.

\section{Theoretical Framework: A Literature Review}

\subsection{Definition and History of Public Management}

Public organisations play a vital role in the economic and social development of most countries; they implement sectoral public strategies, contribute to the resolution of social problems, ensure security, education, health, etc. In general, the missions of these institutions are intended to meet the needs of citizens and are said to be of public interest; and the functioning and governance systems of public administrations have strong specific characteristics, depending on the country where they're established.

However, despite this diversity, the management of public institutions remains complex and very different from that of private companies. The abundant literature on corporate governance has shown a significant effect of good governance practices on corporate performance through the use of various indicators. Kyere and Ausloos (2021) empirically examine the impact of good corporate governance on the financial performance of United Kingdom firms. They show that when the right corporate governance mechanisms are chosen, the finances of a firm can be improved. Indeed, this relationship results from the fact that companies are under increasing pressure from shareholders and market forces.

Similarly, public management has also been the subject of several studies which agree on its complexity due to the particularity of its governance, objectives and its decision-making processes. Lynn (2006) shows that public organizations are becoming increasingly complex as they try to tend to numerous and sometimes conflicting ideas, considerations, demands, structures and cultural elements at the same time.

Thence, in the literature, the functioning of public services is often criticised for its lack of innovation, which is said to be linked mainly to its monopolistic nature, the free services it offers and the lack of resources.

Withal, due to the challenges that governance systems of public institutions face, and due to the impact, their decisions have on the daily lives of citizens, as well as the overall image and competitiveness of countries, strengthening the governance practices of these institutions is the chief concern of researchers, leaders and citizens. Several developments have marked the history of public management. Strategic, legal, regulatory, cognitive, social and organisational innovations have had significant positive impacts.

However, the switch to digital technology has made it possible to improve governance, 
optimise resources, and facilitate the performance measurement of these institutions through the evaluation of citizens' satisfaction of the impact these governance tools have on their daily lives. According to Lefebvre (2019), contrary to preconceived ideas about the immobility of public administration, history shows significant developments and innovations. Today, these innovations are all more accelerated thanks to technological advances, and after bureaucracy and New Public Management (NPM), the new public governance advocates the use of these new technologies.

Notwithstanding that, before looking into the "digital age", it seems necessary to briefly review these major stages in the history of public administration. Bureaucracy was the management style of public organisations for almost two centuries, appointed officials were assigned to administrative tasks that were organised hierarchically, without the participation of citizens. It comes as no surprise that this management style was then be criticised by the general public, because of the 'excessive power' held by the administration.

New Public Management (NPM) on the other hand is a concept born in the 1970s, it strived for better power distribution of political entities. The origins of NPM combine two different currents of ideas. The first, would be the current of "new institutional economies" based on the ideas of user choice, transparency and incentive driven policies (Ostrom, 1974). The second would last in a series of successive waves of commercial managerialism in the public sector (Merkle 1982; Hume 2004; Pollitt, 1990); generating ideas for administrative reform based on management expertise (Martin, 1983). The NPM proposes, according to the objectives of the economy market, reform projects to revise traditional governance and administrative practices motivated by bureaucratic efficiency in the public sector (Osborne \& Gaebler, 1995).

Consequently, public management continues to evolve: bureaucracy, NPM and new public governance showcase significant differences; but the fundamental question of the effectiveness of public administration arises, and to answer it, the administrative structures must be revised; in order to ensure the optimal use of existing resources. Gersonskaya (2019) shows that the ongoing transformational processes include not only the introduction of digital technologies in all sectors of the national economy, but also positive changes in the leadership styles of government structures and methods of government. This requires a complete overhaul of the management style of public resources (Self 2000; Pestoff et al, 2012).

Overall, the improvement of public institutions in a large number of countries was thanks to the modernisation of public administration and more recently, its digitalisation. This improvement can also be explained by several other factors, including the promotion of ethical values such as integrity and transparency, the separation between "politics", "administration", and the new found interest in citizen satisfaction (Casalino, et al, 2013).

In fine, the history of public administration is very rich and showcases a timeline of changes and innovations as the next section addresses.

\subsection{Technological Innovation and Public Management}


Technological innovation has long been attributed to the private sector, and more so than the public sector. When it comes to the private sector, innovation transforms the way business is done and drives business growth. In administrative and public services, in particular, lag behind when it comes to the adoption of new technologies compared to other public services such as healthcare for instance.

The public sector is a set of bureaucratic institutions, the main identifiable problem in public administration would be how to effectively circumvent inefficient bureaucratic accountability. Ineffective, cumbersome, unproductive, but fundamental guarantor of democratic values (Frederickson, 2000; Aberbach \& Christensen, 2005). The question that arises here is how do e-government initiatives, as instruments, help bureaucratic institutions to uphold their democratic values, and support bureaucratic administrative functions? That is, information and communication technologies have been designed and implemented to provide tools, automation and effective support for the existing administrative processes of the bureaucratic organisation, without changing its basic logic (Nohria \& Berkley, 1994).

These new technologies therefore reinforce existing democratic values while optimising existing operating methods (Willcocks \& Mason, 1987). Since the diffusion of information and communication technologies in the 2000s, citizens' expectations of government services changed; they're now seen as a useful tool in the process of rationalisation and personalisation of public administration services (Fountain, 2001). Their impact on the classic four drivers of the NPM agenda, that are efficiency, accountability, decentralisation and commercialisation, has been widely discussed in the literature (Bellamy, 2002).

Likewise, most of the NPM literature considered e-government as the next step in the rationalisation of public administration activities (Bellamy \& Taylor 1998; Fountain 2002; Bellamy, 2002) even if critical positions against this hypothesis exist (Dunleavy et al, 2006), Dunleavy and Margetts (2000) argue that " NPM has been overtaken and replaced by demands from the web-enabled government, which will substantially define a major change in public administration, in advanced industrialised countries for the next decade".

Meanwhile, Gore (1993) has underlined that "e-government will be fairer, more secure, more customer responsive and more efficient than the current paper-based system," highlighting the overlap of fundamental milestones in the NPM ideology and e-government reform policies; it even provides for a theoretical foundation for several e-government initiatives (Hammer 1990; Chadwick \& May, 2003).

E-government can be designed as a policy to uphold the ideology of NPM, it improves the transparency and the accountability of public administrations, but e-government policies can change the nature of the services provided by said administrations. The E-bureaucratic form can be a specific E-government solution that take advantage of new technologies as a means of coordination that aims to improve effectiveness and efficiency, but also helps to uphold the political values of equality and impartiality. Yet since 2012, there has been an acceleration in the rhythm of innovation adoption in the public sector in developed countries.

Today, as it was before in the private sector, the digital switchover is becoming a necessity 
and countries that do not make this transition can be labelled as out of touch with reality. According to Lefebvre P. (2019), three forms of innovation have seen a rapid acceleration since 2012. Chief amongst them, public innovation supported by digital technology where the innovation process is carried by the "start-ups of 'State' with the objective of constituting a State Platform. For this type of innovation, three factors must align: a clear problem, a credible potential solution and an agent carrying the solution. The author describes a second type of public innovation, which is supported by design where the innovation processes tackle poorly defined problems.

Third of all, this innovation is embodied by the implementation of a public policy or a new law on an experimental basis and evaluating its performance before the end of the experiment. "The State Platform » is a concept that is becoming increasingly important in a large majority of countries. According to Chevallier J. (2018), the platform-state requires the adoption of a global strategy of "digital transformation" built around two essential axes: the dematerialisation of all administrative processes and the experimentation on a "digital state platform".

The state "in start-up mode" takes the form of agile structures, endowed with a strong operational capacity that strive to escape bureaucratic routines (Algan \& Cazenave, 2017). As for public data, they're made available to the public to be readily used and constitute an element of added value because this makes it possible to improve knowledge of the needs of citizens. The state would use the same means as companies like Google or Amazon use to better meet the needs of its citizens.

Indeed, these entities organise and exploit information on a global scale in order to know the users and better respond to their requests. The implementation of the State's digital platform is gradual and requires, according to Chevallier J (2018), three components: a unique digital identity for each citizen, a language common to all state applications and data, and protection on personal data exchanged between administrations, and citizens.

\subsection{Digitalisation for Financial Inclusion}

At the centre of global policy-making agendas is now the digitalisation of processes as well as financial products and services. Identifying and promoting initiatives of digital and financial literacy to benefit the financially excluded comes hand in hand with consumer protection, financial education and financial inclusion policies, since financial services have been presented as central to social inclusion (World Bank, 2014), that follow on the heels of micro-finance, so as to adapt rapidly to this changing environment, and at the same time recognise that the citizen's that are financially excluded can be profitable.

Aside from the nonetheless critically moral questions about market inclusion on whether or not said inclusion generates beneficial inclusion as opposed to "adverse incorporation" (Mader, 2016), the digitalisation of financial services is an opportunity for financial autonomy provided financial institutions choose to use this opportunity to benefit the most vulnerable in society instead of making profit at the expense of exclusion of portions of populations. These alternate uses of financial systems should be recognised by public 
administration and by the regulated sector all the while providing inclusivity and accessibility, enabling end-users to make informed decisions about their use of digital financial services (Whitney, Hara \& Whitney, 2018).

Shifting to digital services means shifting to persons to governments or to governments to persons payments, the potential benefits for both are clear; from payment efficiency to cost reduction, speed of payment, security and transparency of payment, etc. However, this shift can also present an interesting first entry point into the formal financial system.

Financial inclusion is access to affordable and accessible financial services, which is an important component of socioeconomic development (Karlan \& Morduch 2010; Beck 2015; Demirgüç-Kunt, Klapper, and Singer, 2017). In developing countries particularly, financial services are provided to a limited segment of the population; but the excluded are likely to be recipients of payments as well, such as government wages and government-sponsored social transfers. In fact, in developing countries, more than five percent of banked adults confessed to have opened their first account to receive a type of the aforementioned public-sector payments, even if doesn't automatically translate into account use (Demirgüç-Kunt, 2015; Bold, Porteous, and Rotman, 2012).

Government agencies as well as public administrations, as service providers, should be able to accurately identify individuals when conducting financial transactions through government-issued identification documents, said documents are necessary to open a bank or mobile money account or to make and receive most digital financial transactions. Governments' biometric financial identification technology can easily replace traditional identification mediums, by leveraging more inclusive identification systems.

In fine, it's clear that the performance of public organisations depends on multiple factors in which different political and public actors are involved. In today's dynamic environment, in the age of Artificial Intelligence and Big Data, knowledge and technological innovation are essential for reforming these organisations and for improving their performance.

And for more than 20 years, questions have been asked about the absorption capacity of innovative processes in ecosystems as rigid as public administrations; however, the questions we ask in this paper are related to the impact these innovative processes have on the digital, social and financial inclusion of a developing country like Morocco.

\section{Problems and Methodology}

Indeed, public sector development often occurs through waves of adoptions of organisational innovations essential to their functioning.

The notions of e-government, e-bureaucracy as well as digital transformation strategies and Big Data analysis tools are very much a reality in industrialised nations; but what of the developing world? What are the most suitable technologies and their absorption, adaptation and performance measurement processes in the public sector for a country like Morocco? How do they impact digital, social and financial inclusion as a whole?

Thence, a qualitative research methodology was dictated by the nature of the problematic, a 
series of interviews were conducted in two public administrations that are major contributors to the state budget, and that have had some notable successes with their digital transformation strategies in Morocco, namely the General Tax Management Agency (DGI) and the National Agency for Land Conservation, Cadastre and Cartography (ANCFCC), these interviews generated qualitative data through the use of a selection of open questions, and follow interviews.

This allows the correspondents to talk in some depth, choosing their own words; the chosen mode was semi-structured interviews, which contains elements of structured and unstructured interviews.

A set of questions have been prepared for all interviewees, and at the same time, additional questions were asked during the interviews to clarify and / or deepen selected issues.

This Interview, that was conducted on the basis of a guide, was an opportunity to collect primary data, and have direct control over the course of the process, as well as a possibility of following up with interviewees on certain takings afterwards; confidentiality was evidently ensured for selected non-public data.

Half a dozen interviews were conducted, over a six-month timeline, with the Director-General of the General Tax Management Agency, the Director-General of the Regional Tax Management Agency, the Director of the Taxpayer Assistance Service, the Director-General of the National Agency for Land Conservation, Cadastre and Cartography, as well as several follow-up inquiries by telephone and mail mediums for additional data collection.

In the next sections, an analysis and a verification of the validity of our results will be initiated, using appropriate analytical methods; the discussed information was based on the primary data collected from the interview process, as well as published, or privileged, documentation provided in the course of the study by the two public administrations.

Document analysis in qualitative research has historically generated effect inducing realities, it treats a text as an empirical entity. This is secondary data collected through documents in both digital and paper form. The collected data is then systematically organised to be interpreted in later steps. Documents provide key insight into the research content and context, using qualitative descriptive content analysis and serving as a complement to other qualitative methods such us interviews; this is often relevant when researching issues pertaining to public management issues (Aktinson \& Hammersley, 1998; Dew, 2005; Rapley, 2018).

Qualitative interview research on another hand is subjective in nature and regarded as descriptive qualitative analysis as it is mainly a description of the interviewee's responses from the interviewee(s). It remains a key research strategy in public management, since administrators and public policy analysts mostly rely much on interviews in a mixed method (O'Sullivan et al, 2016).

The first case study examines the digital transformation strategy of the largest contributor the to the state's budget, a public administration that can be presented like a system of 
information of the territory that's unique to select countries, that is The National Agency for Land Conservation, Cadastre and Cartography.

\section{Case Study I: The National Agency for Land Conservation, Cadastre and Cartography (ANCFCC)}

\subsection{Main Activities}

The National Agency for Land Conservation Cadastre and Cartography (ANCFCC) is responsible on behalf of the State for the registration of land ownership, the publication and preservation of properties registered or in the process of registration, the conservation of land records and documents and communicates to the public all the information mentioned therein, the establishment of cadastral plans within the framework of land registration.

In addition to that, their responsibilities extend to the conservation of the National Cadastre and the revision of the topographic maps of the Kingdom at any scale, carrying out basic infrastructure work relating to geodetic and levelling networks.

Consequently, the ANCFCC has more than 6 million land titles, receives more than two million visitors per year and issues 2.5 to 3 million certificates of ownership annually. With such figures, setting up a connected platform to facilitate administrative procedures for citizens and professionals had become a central project.

\subsection{A Digital Transformation Strategy}

The ANCFCC sets for itself the goals of delivering all of its services digitally and consolidating all of its revenue through a single channel, by putting in place a digitisation plan of action that allows the administration to modernise its processes, to better play its important socio-economic role and to converge with the best international practices. The digitalisation process of the ANCFCC was accelerated following Royal recommendations in December 2015.

Indeed, the objectives of the digital transformation strategy of this administration are the total dematerialisation of the services they provide, the facilitation of procedures for the user, the improvement of the quality of service provided to users, cost reduction, the modernisation of the Administration and the contribution to the public administration digitalisation overall project; Table 1 describes the digital transformation strategy of the agency.

Table 1. Strategies and key projects visions for the future

\begin{tabular}{|l|l|l|l|l|}
\hline Strategy & Government Level & $\begin{array}{l}\text { Date of } \\
\text { initiation }\end{array}$ & Description and Vision & Objectives \\
\hline
\end{tabular}




\begin{tabular}{|c|c|c|c|c|}
\hline $\begin{array}{l}\text { Digitalisation } \\
\text { ANCFCC }\end{array}$ & $\begin{array}{l}\text { ANCFCC + Agency } \\
\text { of Digital } \\
\text { Development }\end{array}$ & 2013 & $\begin{array}{l}\text { - Short term global } \\
\text { digital } \\
\text { transformation } \\
\text { strategy. } \\
\text { Expected } \\
\text { economic, } \\
\text { logistical and } \\
\text { financial } \\
\text { advantages. } \\
\text { Overhaul of nearly } \\
70 \text { production } \\
\text { processes. }\end{array}$ & 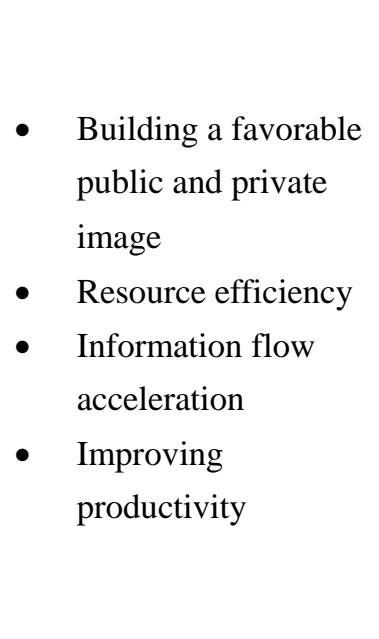 \\
\hline $\begin{array}{l}\text { Security } \\
\text { ANFCC }\end{array}$ & $\begin{array}{l}\text { ANCFCC + Strategic } \\
\text { Committee for the } \\
\text { Security of } \\
\text { Information Systems, } \\
+ \text { General Directorate } \\
\text { of Information } \\
\text { Systems Security, + } \\
\text { Alert and reaction } \\
\text { center for computer } \\
\text { attacks and + National } \\
\text { Commission for the } \\
\text { Protection of Personal } \\
\text { Data. }\end{array}$ & 2007 & 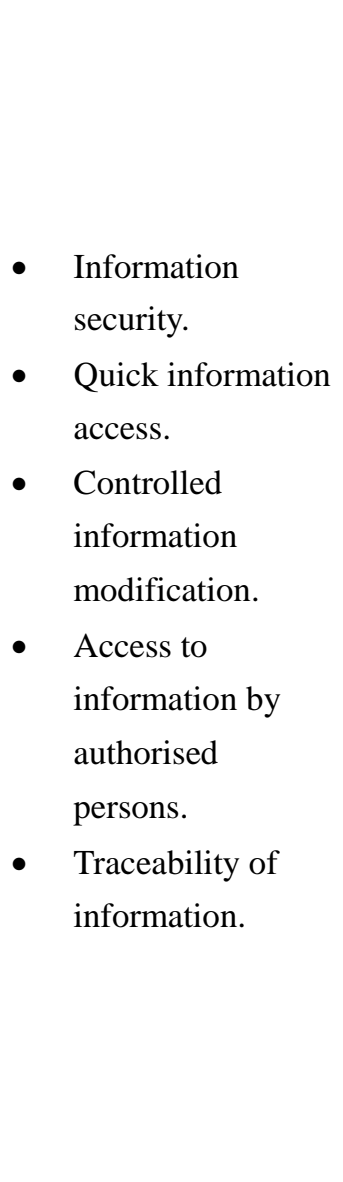 & $\begin{array}{l}\text { Organisational } \\
\text { structure dedicated to } \\
\text { Information System } \\
\text { Security } \\
\text { Mapping of } \\
\text { Information Systems } \\
\text { Controls and } \\
\text { traceability of } \\
\text { administration } \\
\text { operations } \\
\text { Personal information } \\
\text { protection according } \\
\text { to regulation. } \\
\text { Hosting prohibits } \\
\text { sensitive data from } \\
\text { being stored outside } \\
\text { the country. } \\
\text { Implementation by } \\
\text { people, of processes, } \\
\text { technologies, } \\
\text { policies, procedures, } \\
\text { etc. }\end{array}$ \\
\hline
\end{tabular}

Source: Compiled by the authors based on interviews and internal reports.

Hence, and as part of its activities, the ANCFCC has digitised the main services described below. First, the Mohafadati application, launched in June 2017, provides information on land titles and reinforces the security on private properties. Users receive telephone messages to inform them of any changes operated on their property (mortgage, foreclosure, sale, etc.); this new service is a means of combating fraud.

Second, the ANCFCC offers online payment of land conservation rights. The notaries, who 
are responsible for collecting the revenue for the Land Conservation Authority, pay the fees directly online. This service, available 24 hours a day, 7 days a week, reduces processing time and ensures better file traceability.

Thirdly, the ANCFCC has allowed citizens, since February 2018, to obtain their certificates of ownership remotely, by downloading said certificates after completing an online form. An electronic signature was introduced to strengthen the security system. Once downloaded and printed, the certificate must, however, be authenticated. It should be noted that the traditional procedure is maintained for the part of the Moroccan population that's yet to be introduced to online services.

In addition, the ANCFCC has set up a service for the general public to consult in real time all the notices published by the Land Conservation Services in the Official Bulletin, both land titles and requisitions.

Finally, the ANFCC has set up a cadastre and cartography space which targets topographic surveyors who can access various information necessary for the performance of their duties: technical data, cadastral map, consultation of geodetic products, etc. The interface allows them to file the cadastral file online. More than 1,000 cadastral files are processed every day. Land Conservation agents and survey engineers organise training sessions to make this digital system operational. Table 2 summarises the different services offered by the agency and describes in steps the fully digitised process of their usage.

Table 2. Description and Classification of Online Services offered by the ANCFCC

\begin{tabular}{|c|c|c|c|c|c|}
\hline Service & Service Description & Type of Service & Step 1 & Step 2 & Step 3 \\
\hline $\begin{array}{l}\text { Land } \\
\text { Registration }\end{array}$ & $\begin{array}{l}\text { Real time public } \\
\text { consultation of } \\
\text { published notices on } \\
\text { land titles and } \\
\text { requisitions. }\end{array}$ & $\begin{array}{l}\text { Government to } \\
\text { public } \\
\text { (Individuals \& } \\
\text { Businesses), } \\
\text { Public to } \\
\text { Government }\end{array}$ & $\begin{array}{l}\text { Communication } \\
\text { of Information } \\
\text { on regulation }\end{array}$ & $\begin{array}{l}\text { Financial transactions and } \\
\text { Integration of information }\end{array}$ & Feedback \\
\hline $\begin{array}{l}\text { Mohafadati } \\
\text { Application }\end{array}$ & $\begin{array}{l}\text { A free of charge } \\
\text { service that alerts } \\
\text { citizen registered } \\
\text { with the Land } \\
\text { Conservation to any } \\
\text { transaction/operation } \\
\text { involving their } \\
\text { properties. }\end{array}$ & $\begin{array}{l}\text { Government to } \\
\text { public }\end{array}$ & $\begin{array}{l}\text { Subscription to } \\
\text { the service }\end{array}$ & $\begin{array}{l}\text { Communication of } \\
\text { Information on regulation }\end{array}$ & Feedback \\
\hline $\begin{array}{l}\text { Online } \\
\text { Certificates } \\
\text { of } \\
\text { Ownership }\end{array}$ & $\begin{array}{l}\text { Online download and } \\
\text { payment. Document } \\
\text { carry QR codes and } \\
\text { electronic signatures. }\end{array}$ & $\begin{array}{l}\text { Government to } \\
\text { public, Public to } \\
\text { Government }\end{array}$ & $\begin{array}{l}\text { Communication } \\
\text { of Information } \\
\text { on regulations }\end{array}$ & $\begin{array}{l}\text { Financial transactions and } \\
\text { Integration of information }\end{array}$ & $\begin{array}{l}\text { Certificate } \\
\text { download } \\
\text { and service } \\
\text { evaluation }\end{array}$ \\
\hline
\end{tabular}




\begin{tabular}{|c|c|c|c|c|c|}
\hline $\begin{array}{l}\text { Cadastre } \\
\text { and } \\
\text { Cartography }\end{array}$ & $\begin{array}{l}\text { This interface is } \\
\text { adapted to the digital } \\
\text { exercise of the } \\
\text { topographic surveyor } \\
\text { profession. }\end{array}$ & $\begin{array}{l}\text { Government to } \\
\text { Professionals, } \\
\text { Professionals to } \\
\text { Government }\end{array}$ & $\begin{array}{l}\text { Subscription to } \\
\text { the service and } \\
\text { Communication } \\
\text { of data }\end{array}$ & $\begin{array}{l}\text { Integration of information } \\
\text { and filing of data }\end{array}$ & Feedback \\
\hline
\end{tabular}

Source: Compiled by the authors based on interviews and internal reports.

\subsection{The Impacts of the Digital Transformation Strategy}

According to the ANFCC's managers, these digitised services are time saving, improve traceability and secure channels for information exchange. The platform implemented by the ANCFCC has, in fact, made it possible to streamline the processes, improve the transparency and security of all operations for both citizens and professionals while ensuring compliance with the regulatory and technical dispositions.

Moreover, the strategy is a lever for the agency, it makes it possible to align concretely and durably with the technologies that have become an integral part of our everyday life on all levels. This dematerialisation of the services and products made available to the general public and to the agency's partners from the private sector, engineers and topographic surveyors in particular, make it possible to provide faster services outside of time space constraints.

Today, the land conservation agency's framework is now fully digital, with the possibility of filing, consulting and selling documents electronically, as the electronic payment of land conservation rights is now democratised.

Table 3 describes the level of maturity each project has reached as of lately, and the applied security measures, as well as their impact on cost efficiency, performance and customer satisfaction, which is ultimately to do with the overall image of the agency in the country.

Table 3. Degree of Maturity of the ANCFCC's Online Processes \& Impacts

\begin{tabular}{|c|c|c|c|c|}
\hline Process & Project Status & $\begin{array}{l}\text { Cost } \\
\text { Efficiency }\end{array}$ & Security Measures & $\begin{array}{l}\text { Client Satisfaction } \\
\text { Evaluation and } \\
\text { Performance Measurement }\end{array}$ \\
\hline $\begin{array}{l}\text { Archive } \\
\text { Digitisation }\end{array}$ & $\begin{array}{l}\text { Document collection } \\
\text { comprising } 200 \text { million } \\
\text { documents. }\end{array}$ & $\begin{array}{l}\text {-Millions } \\
\text { saved in } \\
\text { annual }\end{array}$ & $\begin{array}{l}\text {-2007: e-foncier } \\
\text { extranet. }\end{array}$ & $\begin{array}{l}\text {-E-monitoring of cost and } \\
\text { time management, }\end{array}$ \\
\hline Cartography & $\begin{array}{l}\text { Cartographic } \\
\text { products of a } \\
\text { scientific and } \\
\text { technical nature } \\
\text { broken down in } \\
\text { digital format, } \\
\text { - Planimetric }\end{array}$ & $\begin{array}{l}\text { paper cost. } \\
-3 \text { to } 5 \text { year } \\
\text { processes } \\
\text { transformed } \\
\text { into } 8-9 \\
\text { month }\end{array}$ & $\begin{array}{l}\text {-2016: Commitment } \\
\text { to confidentiality, } \\
\text { Traceability, } \\
\text { Password } \\
\text { complexity, Security } \\
\text { certificates, etc. }\end{array}$ & $\begin{array}{l}\text {-Monitoring of customer } \\
\text { satisfaction. } \\
\text {-"Transfer of ownership" } \\
\text { Indicator: the country gained } \\
18 \text { spots in the latest World } \\
\text { Bank business climate report. } \\
\text {-"Insolvency settlement" }\end{array}$ \\
\hline
\end{tabular}




\begin{tabular}{|c|c|c|c|c|}
\hline & $\begin{array}{l}\text { geodetic } \\
\text { networks }\end{array}$ & \multirow[t]{5}{*}{ processes. } & \multirow{5}{*}{$\begin{array}{l}\text { - 2017: } \\
+ \text { E-monitoring of } \\
\text { land title operations } \\
+ \text { Land advertising: } \\
\text { official E-bulletin } \\
+ \text { Online forms: } \\
\text { E-forms } \\
+ \text { Ownership } \\
\text { certificate: } \\
\text { E-certificates } \\
\text {-2018: } \\
+ \text { Electronic signature } \\
+ \text { Dashboard and } \\
\text { real-time monitoring } \\
\text { of requests } \\
+ \text { Authentification of } \\
\text { all issued documents } \\
+ \text { Unique code } \\
\text { identifying each } \\
\text { document. }\end{array}$} & \multirow[t]{5}{*}{$\begin{array}{l}\text { Indicator: Morocco was able } \\
\text { to climb } 63 \text { ranks. }\end{array}$} \\
\hline Cadastre & $\begin{array}{l}\text { Cadastral files are } \\
\text { processed exclusively } \\
\text { online. }\end{array}$ & & & \\
\hline $\begin{array}{l}\text { Mohafadati } \\
\text { Application }\end{array}$ & $\begin{array}{l}\text { High rate of registered } \\
\text { citizens, including } 90 \% \text { of } \\
\text { expatriates. }\end{array}$ & & & \\
\hline $\begin{array}{l}\text { Online } \\
\text { Certificates of } \\
\text { Ownership }\end{array}$ & $\begin{array}{l}\text { Online order of the } \\
\text { certificate of ownership. }\end{array}$ & & & \\
\hline $\begin{array}{l}\text { Land Titles } \\
\text { Registration }\end{array}$ & $\begin{array}{l}\text { Higher rate of land } \\
\text { title registration after } \\
\text { the the digitalisation } \\
\text { strategy. } \\
\text { The results are more } \\
\text { tangible in the rural } \\
\text { area of the country. }\end{array}$ & & & \\
\hline
\end{tabular}

Source: Compiled by the authors based on interviews and internal reports.

As a result, the National Agency for Land Conservation, Cadastre and Cartography (ANCFCC) has since then, casually become the largest contributor to the state's budget.

Indeed, one figure will suffice to illustrate that fact, in just four years, and since the digitalisation strategy has been began, the Land Conservation Authority has contributed 16 billion MADs to the state. Some 10 billion dirhams were thus paid to the General Budget and 6 others were devoted to the financing of strategic projects carried out by the kingdom. At the forefront of these, is the launch, for the first time in the history of Morocco, of the two satellites Mohammed VI-A and Mohammed VI-B, fully financed by the ANCFCC.

\section{Case Study II: The General Tax Management Agency (DGI)}

\subsection{Main Activities}

For the past few years, the switch to digital technology has been an important and a strategic priority for the General Tax Management Agency. After initiating the digitalisation process in 2007, the tax administration accelerated its innovation process in 2014 with the aim of achieving its performance objectives and facilitating the reporting and the payment process for taxpayers' benefit.

The main mission of the public administration (DGI) is fiscal, from declaration to tax collection, to control and litigation, affiliated to the Ministry of Economy and Finance and its 
main task is to secure tax revenue. It's thus responsible for assessing and collecting state taxes and determining the bases on which are levied state taxes (corporate tax, income tax, value added tax, registration and stamp duties); certain local taxes managed on behalf of local authorities (housing tax, municipal service tax and business tax), etc.

The DGI ensures compliance with tax law and fights against tax fraud, and since the Moroccan tax system is generally declarative, the control mission therefore occupies a very important dimension; the tax audit is carried out under a strict procedure observing the guarantees offered to taxable individuals.

The DGI is responsible for studying and preparing draft legislative and regulatory texts of a fiscal nature, it studies questions of interpretation of tax provisions and provides information on the responses provided.

\subsection{The Digital Transformation Strategy}

For several years, the DGI has made digital transformation a priority; and as new communications technologies offer prospects for improving the services provided to taxpayers, this administration has made interesting advances in the digitalisation process. Taxation, collection and reimbursement of tax as well as the issuance of certificates electronically are now carried out online, the same applies to the dematerialised management, the scheduling of checks, control and follow-up of disputes.

Table 4 describes the different projects within the digital transformation strategy as well as their level of maturity and general objectives.

Table 4. Strategies and key projects visions for the future

\begin{tabular}{|c|c|c|c|}
\hline Strategy & $\begin{array}{l}\text { Government } \\
\text { Level }\end{array}$ & Description and Vision & Objectives \\
\hline $\begin{array}{l}\text { Digitalisation } \\
\text { and Dematerialisation } \\
\text { DGI }\end{array}$ & $\begin{array}{l}\text { DGI + Agency of } \\
\text { Digital } \\
\text { Development+ } \\
\text { Private partners }\end{array}$ & $\begin{array}{l}\text { A cost saving global digital } \\
\text { transformation strategy. }\end{array}$ & $\begin{array}{l}\text { - E-declaration and } \\
\text { E-payment; } \\
\text { - The dematerialisation of the } \\
\text { registration; } \\
\text { - The enrichment of the } \\
\text { TAWTIK platform services } \\
\text { for notaries; } \\
\text { - Design of the "online } \\
\text { business creation" } \\
\text { (CREOL) application; } \\
\text { - The setting up of platforms } \\
\text { for purchasing electronic } \\
\text { stamps. }\end{array}$ \\
\hline
\end{tabular}




\section{NI Macrothink}

Journal of Public Administration and Governance ISSN 2161-7104

2021, Vol. 11, No. 2

\begin{tabular}{|c|c|c|c|}
\hline Security DGI & $\begin{array}{l}\text { DGI + Private } \\
\text { partners }\end{array}$ & $\begin{array}{l}\text { An Information } \\
\text { System that } \\
\text { supports the } \\
\text { functionalities } \\
\text { offered by the } \\
\text { integrated taxation } \\
\text { system and the } \\
\text { dematerialised } \\
\text { services. } \\
\text { The strengthening } \\
\text { of the platform and } \\
\text { the hardware } \\
\text { infrastructure. }\end{array}$ & 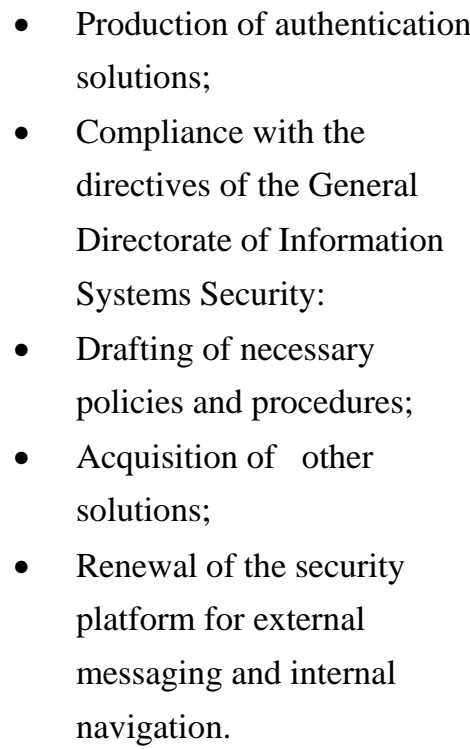 \\
\hline $\begin{array}{l}\text { Building an } \\
\text { Information Capital }\end{array}$ & $\begin{array}{l}\text { DGI + Private } \\
\text { partners }\end{array}$ & 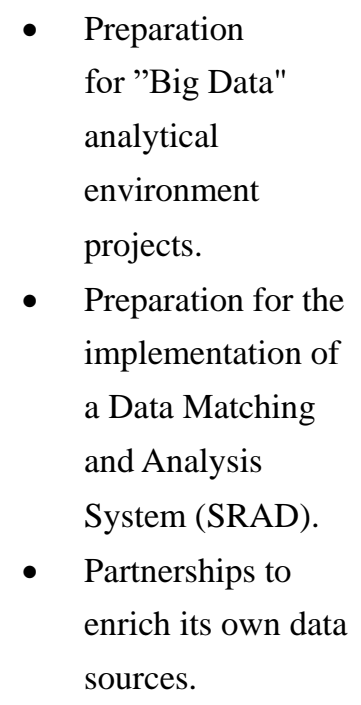 & $\begin{array}{l}\text { - Setting up a Data Lab to } \\
\text { explore and analyse various } \\
\text { issues: monitoring tax } \\
\text { management indicators, } \\
\text { forecasts, fraud detection, } \\
\text { risk analysis and } \\
\text { anticipation. } \\
\text { - Improved Database. }\end{array}$ \\
\hline
\end{tabular}

Source: Compiled by the authors based on interviews and internal reports.

As described above, the DGI has significantly improved the quality of its service through electronic declarations and electronic payments, available online, 7 days a week and 24 hours a day. The system put in place by the tax administration is a real electronic counter. As the name suggests, Simpl (French acronym for 'Online Tax Services') has greatly simplified the filing process.

When it comes to Simpl, two structured modes of declaration exist, the Computerised Forms Exchange Mode, which consists of filling in the form by pre-filling the fields, and then sending it to the DGI; or the Electronic Data Interchange mode, in which a company transmits a file incorporating all the data on a declaration to avoid re-entering data at the Simpl level.

Access to the various Simpl services is possible through a simple authentication by login / 
password which can be done quickly after registering for a 'SIMPL MEMBERSHIP' and obtaining the access code provided by the DGI. The latter authorises companies to appoint a delegate for remote declarations and electronic payments, for which level of security the company can decide on such as drafting, validation, or filing.

The Simpl system has never stopped evolving, after the implementation of Simpl-TVA in 2007, the DGI established Simpl-IS in 2009 and Simpl-IR in 2014; the differences are explained in Table 5, and the rest of the digitised services this public administration offers are described as follows in the same table.

Table 5. Description and Classification of Online Services offered by the DGI

\begin{tabular}{|c|c|c|c|}
\hline Service & Service Name & Service Description & Type of Service \\
\hline \multirow{2}{*}{$\begin{array}{l}\text { Integrated } \\
\text { Taxation } \\
\text { System, } \\
\text { Application } \\
\text { (DARIBATI) }\end{array}$} & $\begin{array}{l}\text { SIMPL-Registration } \\
\text { and Stamp }\end{array}$ & $\begin{array}{l}\text { An electronic registration, consultation and } \\
\text { payment system has been set up for the benefit of } \\
\text { notaries, accountants and chartered accountants. }\end{array}$ & \multirow[t]{9}{*}{$\begin{array}{l}\text { Government to } \\
\text { public, Public to } \\
\text { Government }\end{array}$} \\
\hline & $\begin{array}{l}\text { SIMPL-Local } \\
\text { Taxation }\end{array}$ & $\begin{array}{l}\text { Allows the submission of local taxation } \\
\text { declarations electronically. }\end{array}$ & \\
\hline \multirow{7}{*}{$\begin{array}{l}\text { (Local } \\
\text { taxation, } \\
\text { Basis, } \\
\text { Registration, } \\
\text { Collection, } \\
\text { Accounting, } \\
\text { Control, } \\
\text { Legal affairs, } \\
\text { Forced } \\
\text { collection) }\end{array}$} & $\begin{array}{l}\text { SIMPL-IR } \\
\text { (Professional } \\
\text { Income) }\end{array}$ & $\begin{array}{l}\text { Commissioning of new declarations; New } \\
\text { graphic charts and bilingual versions. }\end{array}$ & \\
\hline & SIMPL-Refund & $\begin{array}{l}\text { Allows online filing and monitoring of refund } \\
\text { requests. }\end{array}$ & \\
\hline & SIMPL-Certificates & $\begin{array}{l}\text { Deployment of all certificates issued online in } \\
\text { bilingual versions. }\end{array}$ & \\
\hline & SIMPL-VAT & $\begin{array}{l}\text { - Adaptation and Revision of declaration; } \\
\text { - Integration of business controls for } \\
\text { statement of deductions. }\end{array}$ & \\
\hline & $\begin{array}{l}\text { SIMPL-IS } \\
\text { (Taxable Income) }\end{array}$ & $\begin{array}{l}\text { - New graphic charts and bilingual } \\
\text { versions; } \\
\text { - Implementation of the normal and } \\
\text { capped progressive rates at the level of } \\
\text { the declaration of taxable income; }\end{array}$ & \\
\hline & Tele-payments & $\begin{array}{l}\text { - Membership of participatory banks in } \\
\text { the E-payment system; } \\
\text { - New online payment service called } \\
\text { "PaybyBank". }\end{array}$ & \\
\hline & Electronic Stamp & $\begin{array}{l}\text { - Dematerialisation of stamps, permits } \\
\text { and licenses; } \\
\text { - Integration of a module for monitoring }\end{array}$ & \\
\hline
\end{tabular}




\begin{tabular}{|c|c|c|}
\hline & stamp sales. & \\
\hline SIMPL-Claim & Consultation of online feedback and claims. & \\
\hline Decision Information System & $\begin{array}{l}\text { Overhaul of the Decision Information System } \\
\text { aimed at constituting an analytical system fed by } \\
\text { financial data, Business System data, as well as } \\
\text { partner's data. }\end{array}$ & \begin{tabular}{|l|} 
Government to \\
Partners and \\
Public, Partners and \\
Public to \\
Government
\end{tabular} \\
\hline $\begin{array}{l}\text { Development of an Electronic } \\
\text { Guide }\end{array}$ & Interactive interface, with guides and videos. & $\begin{array}{l}\text { Government to } \\
\text { Public }\end{array}$ \\
\hline $\begin{array}{l}\text { Dematerialization of Litigation } \\
\text { Management }\end{array}$ & Application designed to process e-complaints. & $\begin{array}{l}\text { Government to } \\
\text { public, Public to } \\
\text { Government }\end{array}$ \\
\hline $\begin{array}{l}\text { Automatisation of Dunning } \\
\text { Letters }\end{array}$ & $\begin{array}{l}\text { - } \quad \text { Automated fault identification and } \\
\text { generation of tax obligations. } \\
\text { - Dematerialisation of reminder letters } \\
\text { and e-payment of dunning letters. }\end{array}$ & \begin{tabular}{|l|} 
Government to \\
Government, \\
Partners and \\
Public, Government, \\
Partners and Public \\
to Government
\end{tabular} \\
\hline Electronic Assistance & $\begin{array}{l}\text { - Strengthening of electronic assistance } \\
\text { and online appointment management } \\
\text { system; } \\
\text { - Setting up a "Chatbot" (in progress). }\end{array}$ & $\begin{array}{l}\text { Government to } \\
\text { Public }\end{array}$ \\
\hline
\end{tabular}

Source: Compiled by the authors based on interviews and internal reports.

It should be noted that online declarations and electronic payments have become compulsory with the Finance Act of 2017 for companies and of 2018 for individuals.

And with regards to electronic payments, they're initiated thanks to bank, direct debit orders are initiated through different channels: Bank card, e-banking, etc.

To assist taxpayers, the DGI has initiated several training and information campaigns for users, as discussed above.

\subsection{The Taxpayer's Perspective}

These online services seem to be appreciated by taxpayers since, like any digital service, they save the user travel expenses and waiting times at counters. This can be highlighted by the number of certificates withdrawn online, alone, that increased from 16,857 in 2016 to 644,782 in 2018 , i.e. a growth rate of $372 \%$.

Digitalisation has not only simplified the electronic declaration and electronic payment processes, but it also allowed users to benefit from assistance in calculating taxes and 
surcharges, reducing errors by checking the consistency of the amounts entered, checking for mandatory fields and for reporting errors. For users who have already made a remote declaration, several fields are pre-filled with data from the previous declarations.

This new approach resulted in an improvement in the relationship between taxpayers and the DGI and has had the impact of a significant drop in the number of complaints and disputes which were sometimes caused by simple entry errors.

\subsection{The DGI's Perspective}

The digital switchover has benefited the DGI by the modernisation of its processes and allowing the administration to contribute to the government's "E-gov" project.

Indeed, change management had to be accompanied by training and an upgrading of Human Resources' skills, especially in the information systems' department. The reorganisation of the DGI was carried out by the creation of entities dedicated to the implementation and support of the new strategy. The digital switchover could not be operational without a review of working methods, strengthening of skills, upgrading of information systems, and consistent reviews of procedures.

And although the digital transformation of the DGI brought about a new order, the results and positive impacts were felt from the first years of the deployment of the strategy. This digitalisation has had a positive impact on gross revenue which improved by $26.2 \%$ between 2015 and 2018 (125.7 billion MADs to 158.8 billion MADs).

Some of the most interesting positive impacts of the strategy have been the rapid processing of remote declarations, the reduction in the demand at the counters, and the drop in the number of complaints; this has resulted in greater availability of managers and a redeployment of resources to bigger added value tasks, control tasks in particular, were positively impacted.

To analyse the improvement in the performance of the DGI more exhaustively, other indicators may be examined, such as tax collection, the numbers of businesses and individuals filing a tax return, the recovery period, the number of companies inspected, etc; but in the absence of such data, we elected to postpone the study of the quantified impact of the digital transformation strategy on the DGI to a future study.

As it's, this strategy has had a major role in enriching and increasing the reliability of information used in the DGI's control techniques.

\section{Discussion}

Measuring the performance of public organisations and their ability to respond to the needs of citizens is a major challenge facing governments and states all over the world. Before the digitalisation, it required the use of management control tools in which performance targets were predefined. Today, measuring the efficiency of such public administration is much easier. For example, measuring citizen satisfaction is now simpler, and less abstract, since citizens are called upon to assert their opinions on the services rendered and are sometimes called 
upon to give ideas through dedicated platforms for the improvement of these services.

For Morocco, technological innovation in the public sector has strong implications as presented in the two case studies of ANCFCC and DGI. The transition to the digital age allows, for improvements both internally (management, tasks, roles of officials, etc.) and externally (administration-citizen relationships, etc.); and the benefits of the digital switchover are numerous and their impacts are significant for both the government and citizens.

Before the digital switchover, as opposed to the situation today, numerous surveys showed citizens' dissatisfaction with administrative public services and criticism focused on the quality of service, non-compliance with deadlines, the lack of traceability of files, etc. The efforts made within the Moroccan public administrations have significantly improved citizen satisfaction. The results of the plans of action put in place as well as the measures undertaken by public administration can be assessed through various indicators, the number of claims filed, which has been decreasing is chief amongst them; for confidentiality reasons, other indicators are not shown in our research as some of these surveys/studies are still in progress.

Digitals tools are a means of improving the performance and the efficiency of administrative public services. The development of digital technology, for both DGI et ANCFCC, has made it possible to meet citizens' needs through a rapid service, which can be done (often) remotely and can sometimes be less costly, services are therefore of better quality and better suited to citizens' expectations.

The digitalisation allows for a transformation of the relationship between agents and users, as co-producers of services. This new form of collaboration improves confidence, transparency and offers, in addition to existing traditional services, new very useful and sometimes even personalised services that meet very specific needs.

Indeed, the deployment of these tools in the administrations has allowed a simplification and an automation of the procedures, as well as a reorientation of the available resources towards more important tasks, such as control tasks for the DGI.

According to DGI and ANCFCC, even if sometimes reluctance can be noted at the beginning of the deployment of these tools, several employees come to understand the importance of adopting and encouraging the "digital culture". They find themselves in an environment of collaboration, reflection and not merely execution, they're able to be more creative and autonomous, hence the concept of "agile management".

Overall, this digital switch requires a review of working methods, a strengthening of human resources skills, an upgrading of information systems, etc; and it can be assumed that substantial budgets are needed for the digital switchover, it's not always the case. Indeed, DGI's and ANCFCC's managers explain that most of the time the saved costs are substantially more important than the amounts invested. This affirmation converges with Pezziardi P. and Verdier H. (2016) conclusions when they showed that 2.0 services are often designed quickly by small teams, with reduced budgets. 
These digital tools are useful when it comes to keeping abreast of what is happening in the world, access certain services, but also to maintain social and family ties. Conversely, we can also wonder whether access to digital technology doesn't promote a certain social distortion. Because next to it, there are all those who, for various reasons, have limited access to it, or even no access at all. Would digital technology then encourage social, cultural or even economic exclusion?

This debate, already raised elsewhere, will certainly arise in Morocco, especially as, more and more, we are moving towards the multiplication of the dematerialisation of the services offered to the community. Which, inevitably, will lead to inequalities in access to digital technology between those who are more educated and better trained and those who are not.

Hence the importance of the 'Maroc Digital 2020' strategy, which should embody a strong political will to reduce distortions and make digital technology a real lever for social inclusion.

Still today in Morocco, to benefit from online administrative services, online banking is often necessary. Therefore, only citizens who have access to a bank account, and can afford fees attached to banking services, can have access to online services.

Thus, the development and the digitalisation of administrative services cannot be dissociated from the concept of financial inclusion, which consists of facilitating access and use of financial services and products to all Moroccan adults, even the most deprived.

Financial inclusion is considered an important vector of socio-economic development, for which national strategies are put in place and whose objective is to achieve "financial inclusion" for the entire eligible population. This financial inclusion is often assessed by various indicators including the percentage of adults who have a bank account, this percentage stands at $68 \%$ in the case of Morocco according to the latest statistics; it should be noted, however, that the inclusion rate has increased over the years.

The Moroccan population is considered as "connected" with nearly 21 million mobile Internet subscribers and can take advantage of the penetration of mobile phones and the Internet, in order to use mobile payment which allows greater financial inclusion of the population. In recent days, Morocco has managed to put in place the solutions necessary to make mobile payment operational, to allow cash transfer and transactions payments. New technologies applied to finance are targeting this niche of adults who were unbanked due to high banking costs, distance from bank branches, or lack of official documents.

To a certain extent, Morocco continues to face the challenge of financial inclusion and will have to exploit all the opportunities offered by digital tools to secure transactions and gain the trust of users. The implementation of mobile payment will certainly have an impact on citizen's usage of public administrations' digital services; similarly, the digitalisation of public administration's services is likely to positively influence social, digital and financial inclusion in Morocco, whether be it by increasing the banking rate of the country or the democratisation of mobile payment solutions. 
More than financial inclusion, the digital switchover has the potential to increase the engagement and the social inclusion and participation of users in multi-level governance design and public sector efficiency, changing the boundaries of public service delivery, creating better targeted public and personal value added through the co-production of said services, and strengthening trust through digital outreach.

\section{Concluding remarks and Recommendations}

Citizens and businesses today expect public sector information and services to be accessible online, and free of charge. Governments therefore have many motivations to meet these expectations by investing in a comprehensive digital transformation of the public sector. In the case of Morocco, digital projects that exist at multiple levels in different public administrations, should produce better results when the different phases of the transformation are complete and integrated.

Despite all the progress made, Moroccan public administrations are far from reaping the full benefits of the digitalisation such as social and financial inclusion. To do this, there's a need to deepen digital transformation strategies, beyond providing online services through portals. It means looking for opportunities implement innovative frameworks and improve productivity, collaboration scales, process efficiency. A strong involvement of employees in the redefinition of working methods and missions is necessary for managers to avoid counterproductive actions.

Furthermore, public administrations ought to define various quantified indicators to measure the performance as well as the contributions of the digitalisation strategy at various levels, from efficiency, time saving, cost reduction and return on investment measures, to client satisfaction measures, etc. The strategy should take place in an open ecosystem, which not only promotes interactions between public sector administrations, as a priority, but interactions with the private sector, with universities and researchers as well. To do so, the question of a digital identity that's usable across organisations, presents itself again, as discussed above in the literature.

A digital transformation should strive towards strengthening and redefining the relationship between the citizen and the administration through collaboration, the user, here the citizen, must become a co-producer of services through concrete recommendations for service improvement. As digital technologies become more increasingly integrated in public administration processes, the need for effective financial education increases as well. Awareness should be raised on the fact that digital technologies provide tools to support and improve lives. This is possible if awareness of the benefits, risks and different types of services offered is cultivated, as well as awareness of the financial products and services delivered through digital means, like electronic money, mobile banking, digital credit and insurance services, that come with the usage of said services.

Financial education, as well as alternative payment methods tailored to individual needs with personalised information and advice, makes financial information palatable to larger audiences, and relates to the implications of digitalisation across the public sector for social 
and financial inclusion. In most countries where governments have already carried out state platforms, an important issue arises, that is the management of reference data, personal data protection, and data quality.

Today, the state of health emergency and movement restriction caused by the Covid19 crisis affects the daily lives of citizens significantly, making it difficult to access public services, making the issue of state platforms a more urgent matter. To remedy that, several actions have been taken in Morocco and the digital transformation strategy was accelerated to improve public administration efficiency to meet citizens' needs during the pandemic. Thus, a decree-law relating to the state of health emergency favouring digital solutions was adopted in response to the situation.

During this period, the Ministry of the Economy, Finance and Administration Reform has implemented new reforms where electronic submission of documents has become compulsory via online portals, accompanied with the digitisation of documents in public administrations. The Digital Development Agency, has been coordinating with the Ministry of the Economy and Finance other actions including the establishment of a portal for a digital office for administrative correspondence, the dematerialisation of administrative documents, electronic signatures management and workflow management.

These measures have made it possible to ensure the continuity of administrative work, reducing queues in front of public bodies, limiting the movement of citizens and therefore the spread of the virus. However, equal access to public services is called into question since certain categories of the population cannot benefit from this due to the fact that they are not Internet users or that they are present in areas of the territory with no Internet coverage.

The fact remains that little to no quantitative information is available at present to assess the extents, as well as the impact of the acceleration of the strategy. This will be the subject of a future follow up article to assess the effects the Covid19 pandemic has had on the digitalisation of the Moroccan public administration.

\section{References}

Aberbach, J. D., \& Christensen, T. (2005). Citizens and Consumers. Public Management Review, 7(2), 225-246. https://doi.org/10.1080/14719030500091319

Aktinson, P., \& Hammersley, M. (1998). Ethnography and participant observation. Strategies of Qualitative Inquiry. Thousand Oaks: Sage, 248-261.

Anderson, C. A., Gentile, D. A., \& Buckley, K. E. (2007). Violent Video Game Effects on Children and Adolescents. https://doi.org/10.1093/acprof:oso/9780195309836.001.0001

Bellamy, C. (2001). Reinventing government in the information age: international practice in IT-enabled public sector reform. edited by R. Heeks. Routledge, London, 1999. ISBN 0-415-19037-1, 386 pp. Public Administration \& Development, 21(3), 271.

Bold, C., Porteous, D., \& Rotman, S. (2012). Social cash transfers and financial inclusion: Evidence from four countries. Population (in millions), 193(46), 109. 


\section{I Macrothink}

Journal of Public Administration and Governance ISSN 2161-7104

Casalino, N., Draoli, M., \& Martino, M. (2013, May). Organizing and Promoting Value Services in Public Sector by a New E-government Approach. In Proceedings of XIV Workshop dei Docenti e Ricercatori di Organizzazione Aziendale (WOA 2013), Università La Sapienza, Rome.

Chadwick, A. (2003). Bringing E-Democracy Back In. Social Science Computer Review, 21(4), 443-455. https://doi.org/10.1177/0894439303256372

Chadwick, A., \& May, C. (2003). Interaction between States and Citizens in the Age of the Internet: "e-Government" in the United States, Britain, and the European Union. Governance, 16(2), 271-300. https://doi.org/10.1111/1468-0491.00216

Chevallier, J. (2018). Vers l'État-plateforme ? Revue Française d'administration Publique, 167(3), 627. https://doi.org/10.3917/rfap.167.0627

Cordelia, A. (2007). E-government: Towards the E-Bureaucratic Form? Journal of Information Technology, 22(3), 265-274. https://doi.org/10.1057/palgrave.jit.2000105

Cordella, A., \& Bonina, C. M. (2012). A public value perspective for ICT enabled public sector reforms: A theoretical reflection. Government Information Quarterly, 29(4), 512-520. https://doi.org/10.1016/j.giq.2012.03.004

Cordella, A., \& Iannacci, F. (2010). Information systems in the public sector: The e-Government enactment framework. The Journal of Strategic Information Systems, 19(1), 52-66. https://doi.org/10.1016/j.jsis.2010.01.001

Demirgüç-Kunt, A., Klapper, L. F., Singer, D., \& Van Oudheusden, P. (2015). The global findex database 2014: Measuring financial inclusion around the world. World Bank Policy Research Working Paper, (7255).

Demirguc-Kunt, A., Klapper, L., \& Singer, D. (2017). Financial inclusion and inclusive growth: A review of recent empirical evidence. Policy Research Working Paper 8040, World Bank, Washington, DC.

Desmarchelier, B., Djellal, F., \& Gallouj, F. (2019). L'innovation dans les services publics à la lumière des paradigmes de l'administration publique et des perspectives de l'innovation de service. Revue Européenne d'Économie et Management des Services, 2019(8), 91-120.

Dew, K. (2005). Documentary analysis in CAM research: Part 1. Complementary Therapies in medicine, 13(4), 297-302.

Direction Générale des Impôts, Maroc (2018). Rapport d'Activité.

Direction Générale des Impôts, Maroc (2019). Rapport d'Activité.

Dunleavy, P., Margetts, H., Bastow, S., \& Tinkler, J.(2006). Digital Era Governance-IT Corporations, the State and e-Government. New York: Oxford University Press. Social Science Computer Review, 26(2), 254-257.

Eccles, R. G., Nohria, N., \& Berkley, J. D. (1992). Beyond the hype: Rediscovering the 
essence of management. Harvard Business School Press; Apparent First Editon edition (1992-01-01).

Fountain, J. E. (2004). Building the virtual state: Information technology and institutional change. Brookings Institution Press.

Frederickson, H. G. (2000). Can Bureaucracy Be Beautiful? Public Administration Review, 60(1), 47-53. https://doi.org/10.1111/0033-3352.00061

Gersonskaya, I. (2019). Leading Role of the Public Sector in the Digitalisation of Economy. Proceedings of the 5th International Conference on Social, Economic, and Academic Leadership (ICSEALV 2019). https://doi.org/10.2991/assehr.k.191221.203

Hume, L. J. (2004). Bentham and bureaucracy. Cambridge University Press.

Karlan, D., \& Morduch, J. (2010). Access to finance. In Handbook of development economics (Vol. 5, pp. 4703-4784). Elsevier.

KPMG (2018). La Digitalisation du Secteur Public au Service de l'Expérience Citoyenne: Le Secteur Public au Luxembourg. https://home.kpmg/lu/en/home/insights/2019/11/digitalisation-secteur-public-experience-cito yenne-service-luxembourg.html

Kranzberg, M., \& Merkle, J. A. (1982). Management and Ideology: The Legacy of the International Scientific Management Movement. The American Historical Review, 87(2), 425. https://doi.org/10.2307/1870130

Kyere, M., \& Ausloos, M. (2020). Corporate governance and firms financial performance in the United Kingdom. International Journal of Finance \& Economics, 26(2), 1871-1885. https://doi.org/10.1002/ijfe.1883

Lefebvre, P. (2018). Innovation et Administration: Quelle histoire (XIXe-XXe siècle)?. HAL.

Lynn, J. (2006). Public Management: Old and New. https://doi.org/10.4324/9780203964774

Mader, P. (2016). Card crusaders, cash infidels and the holy grails of digital financial inclusion. Behemoth-A Journal on Civilisation, 9(2), 59-81.

Mansfield, H. C., \& Ostrom, V. (1974). The Intellectual Crisis in American Public Administration. Political Science Quarterly, 89(4), 871. https://doi.org/10.2307/2148912

Martin, S. (1983). Managing without managers: alternative work arrangements in public organizations (Vol. 147). SAGE Publications, Incorporated.

McKinsey \& Company (2014). Public-sector Digitisation: The Trillion-dollar Challenge. https://www.mckinsey.com/business-functions/mckinsey-digital/our-insights/public-sector-di gitization-the-trillion-dollar-challenge\#

Ministère de la Réforme de l'Administration et de la Fonction Publique, Maroc (2018). Plan National de la Réforme de l'Administration. https://www.mmsp.gov.ma/fr/decline.aspx?m=1\&r=380 
O'Sullivan, E., Rassel, G., Berner, M., \& Taliaferro, J. (2016). Research methods for public administrators. Routledge.

OECD (2017). OECD Digital Economy Outlook, OECD Publishing, Paris. https://www.oecd.org/digital/oecd-digital-economy-outlook-2017-9789264276284-en.htm

OECD (2018). G20/OECD INFE Policy Guidance on Digitalisation and Financial Literacy. https://www.oecd.org/financial/education/g20-oecd-infe-policy-guidance-digitalisation-financ ial-literacy-2018.htm

Oxborne, D., \& Gaebler, T. (1995). Reinventing government. Journal of Leisure Research, 27(3), 302.

Pestoff, V. (2012). Co-production and third sector social services in Europe: Some concepts and evidence. Voluntas: International Journal of Voluntary and Nonprofit Organizations, 23(4), 1102-1118.

Pestoff, V., Brandsen, T., \& Verschuere, B. (Eds.). (2013). New public governance, the third sector, and co-production. Routledge.

Pezziardi, P., \& Verdier, H. (2016). Des “start-up d'État" pour transformer en souplesse l'Administration. Le journal de l'École de Paris du management, (4), 22-29.

Rapley, T. (2018). Doing conversation, discourse and document analysis (Vol. 7). Sage.

Self, P. (2000). Rolling back the market: Economic dogma and political choice. London: Macmillan.

Sokoloff, P. (2016). Le Big data et l'Open data au service des collectivités. In Annales des Mines-Responsabilité et environnement, 4(84), 41-46.

Turrini, A., \& Valotti, G. (2016). Public Management Reforms in Italy: A Renaissance Revival? Public Administration Review, 76(3), 393. https://doi.org/10.1111/puar.12560

Verdier, H., \& Colin, N. (2012). L'âge de la multitude: Entreprendre et gouverner après la révolution numérique. Armand Colin.

Whitney, G., Hara, S., \& Whitney, L. (2018). Study on risks and opportunities of digitalisation for financial inclusion. The perspective of vulnerable users in Estonia, Italy and UK with a focus on groups covered by the European Accessibility Act. Financial Services User Group (FSUG), (78).

Willcocks, L., \& Mason, D. (1987). Computerising: Lessons from the DHSS Pensions Strike. Employee Relations, 9(1), 17-22. https://doi.org/10.1108/eb055092

World Bank (2014). Global Financial Development Report 2014: Financial Inclusion. Washington DC: World Bank Group.

\section{Copyright Disclaimer}




\section{Macrothink}

Journal of Public Administration and Governance ISSN 2161-7104

Copyright for this article is retained by the author(s), with first publication rights granted to the journal.

This is an open-access article distributed under the terms and conditions of the Creative Commons Attribution license (http://creativecommons.org/licenses/by/4.0/). 